\title{
Replacement depreciation and price regulation
}

\author{
IJ Lambrechts \\ Department of Business Management, University of Stellenbosch, Stellenbosch
}

\begin{abstract}
Price regulation occurs quite commonly amongst natural monopolies which frequently include public utilities. In South Africa and in certain countries in Africa, there has recently been a revival of price regulation in certain industries and enterprises, where competition is limited or non-existent. Price regulation can be applied in a multitude of ways. Because of the importance of the price levels (historical and replacement) in the price setting exercise, the focus in this paper will be on the issue of depreciation to arrive at the final prices.

The electricity utility industry was historically viewed as a highly mature and heavily regulated natural monopoly. In many parts of the world, electricity utilities have already been deregulated to a large extent and in the United States the process was preceded by a process of unbundling or ringfencing of the main divisions, i.e. generation and distribution. Even the network component of transmission, traditionally seen as natural monopolies, was deregulated to a large extent. The deregulation process, whether fully or partially, emphasised the requirement for a detailed explanation for a specific price level. The need for acceptable and transparent selling prices has, therefore, not disappeared. Regulatory pricing is consequently a vital component of pricing at this stage and in the restructured industry it will continue to play an important role because of a limited number of participants.

In other sectors of the South African energy industry too, the deregulation process has either not started or has not been completed. Price regulation is presently and will in future be applicable to the liquid fuels industry, which includes the pipeline of Petronet as well as gas pipelines. Other industries which are being price regulated at the moment include water, medicine, telecommunication (fixed lines) and postal rates. Although the economic regulation for these industries may differ substantially, the principles applying to depreciation calculations would be similar.
\end{abstract}

Replacement depreciation produces lower profit figures during periods of inflation. Quoted companies often oppose this system because of a lack of taxation recognition on income and the adverse effect on earnings per share.

This paper covers the calculation of depreciation by price regulators where assets are not diversified (single assets). Shorter depreciation lifetimes based on historical cost result in an automatic provision for replacement depreciation. The extent of the provision would be a function of the difference between the actual and selected lifetimes, income tax rates, re-investment rates and the extent of the financial gearing ratio. Provision for replacement depreciation may be reduced significantly, if not reduced completely, by reducing depreciation lifetimes.

Keywords: Depreciation, replacement cost, depreciation lifetimes, price regulation

\section{Introduction}

Price regulation occurs quite commonly amongst natural monopolies (Baumol 1980; Howe \& Rasmussen 1982; Tysseland \& Gandhi). Public utilities are frequently natural monopolies (Doppegieter et al 1989). In these industries one firm is usually able to supply the entire market at a lower cost than two or more firms, with the result that very large economies of scale are normally possible (Webb 1976). These economies result normally from factors, such as increasing long-terms volumes, higher diversity (maximum demands not coinciding) resulting in lower overcapacity levels, large fixed investments resulting in a strong decline in average costs with increasing utilisation and economies in financing and marketing costs enabling the monopoly to serve the market at a lower cost, e.g. as result of less duplication and competition (Doppegieter et al 1989).

Price regulation could be applied in a multitude of ways. It consists usually of the determination of the cost level for the test period, capital (or asset) 
base requirement and the required rate of return. The required rate of return (or allowed or target rate of return) which is related to the cost of capital (which is amongst others based on assumptions around the gearing issue) is applied to the relevant capital base to determine the required income. The difference between the required income (based on the test period) and the income presently being earned indicates the price adjustment to be implemented. In calculating the costs and the capital base, various valuation approaches could be followed, e.g. original cost, fair values and replacement costs. In spite of occasional opposition against historical cost because of various reasons, the fact remains that firms that are not providing for higher replacement costs could face financial distress because of insufficient provision for financial returns, resulting in continuity problems.

The calculation of selling prices involves the combination of many determining factors to arrive at the desired end result (Doppegieter \& Lambrechts 1985). Examples are the combination of various cost structures (previous, expected or optimum), the definition of the capital (asset) base (equity or total capital based on previous, expected or optimum values) and the level of the required rate of the return. The literature on these aspects is very broad and extensive.

The objective of this paper is not to discuss the well developed literature on regulatory methodologies employed by various consumers or selling price determination commissions. Each country has it own price control experiences and these are well documented. The important aspect is that the ultimate selling price should be reasonable and defensible; not over or under charging the consumer (Turvey \& Anderson 1977). Because of the importance of the price levels (historical and replacement) in the price setting exercise, the focus will be on depreciation issues to arrive at the final prices (Nelson \& Primeaux 1984). The question will be asked to what extent assets should be revalued to arrive at a true and reliable end result (price). Whether the revaluation is by means of current costs, indexed historical costs, replacement costs, modern equivalent assets, market or economic valuations is completely irrelevant for these particular calculations and exercises.

Depreciation accounting can normally be seen as a system of accounting to distribute the cost or other basic value of tangible capital assets over the estimated useful life of the unit (which may be a group of assets) in a systematic and rational manner. Depreciation for a specific year is the portion of a total charge under such a system that is allocated to the year. Depreciable amounts are allocated to each accounting period during the useful life of the asset by following a variety of systematic methods. The consistent use of the selected method is neces- sary, irrespective of the level of profitability of the enterprise and of taxation considerations, in order to provide comparability of the results of operations of the enterprise from period to period. Depreciation is, therefore, the consumption of the property resulting from forces, which includes wear and tear, decay, some action caused by the elements, inadequacy, obsolescence and public requirements. It entails the loss in the service value, which is not restored by current maintenance. The service value of the property diminishes gradually and cannot be postponed indefinitely through maintenance, although maintenance could indeed prolong the service life of an asset in some circumstances (Bakker 1974).

Virtually all income statements include an amount described in the income statement as depreciation under costs. In a manufacturing organisation the calculation of the cost of goods sold would normally take into account depreciation relating to the plant and equipment being used in the operations. Depreciation is generally an important item in profit measurement and frequently represents a significant part of total overhead costs (Archer 1981). In an age of technological change it is becoming increasingly rare for long-term assets, such as plant and equipment, to be replaced by an identical asset. As a result, the additional amount that would almost inevitably have to be paid for replacement in a period of inflation will be a mixture of costs relating to improvement and inflation. It is consequently difficult to separate these two categories (Ernst \& Whinney 1982; Kirkman 1985).

In the competitive/commercial sector, selling prices charged by enterprises are determined by the forces of supply and demand in the market place and here the calculation of depreciation of such entities is largely a matter of accounting necessity. In price-controlled sectors, the calculation of depreciation is of direct economic significance, since it is typically incorporated into the rates of revenue requirements of a regulated entity as a necessary cost of the business. Although the depreciation expense for regulated industries has traditionally been viewed as the recovery of capital invested in an enterprise, double digit inflation rates in certain years and the completion of multibillion projects would cause a resurgence of interest in regulation based upon notions of current or replacement cost. An important issue within the replacement cost paradigm is the use of depreciation expense as a means of generating funds for the replacement of assets at current price levels rather than simply being viewed as the recovery of historically invested capital. Much of the literature regarding replacement cost regulation has focused on underlying principles, determining an appropriate rate of return, and the manner in which replacement cost should be calculated (Doenges 1983). 
In South Africa and in certain countries in Africa, there has recently been a revival of price regulation in certain industries and enterprises where competition is limited or non-existent. The electricity utility industry was historically viewed as a highly mature and heavily regulated natural monopoly. In many parts of the world electricity utilities have already been deregulated and, in the United States, the process was preceded by a process of unbundling or ringfencing of the main divisions, i.e. generation, transmission and distribution. In many cases where the deregulation process was completed the end-result nevertheless reflected a monopolistic function. The need for acceptable and transparent selling prices has, therefore, not disappeared. Regulatory pricing is consequently a vital component of pricing at this stage. Even in the restructured industry it will continue to play an important role because of a limited number of participants.

In other sectors of the South African energy industry too the deregulation process has either not started or has not been completed. Price regulation is presently and will in future be applicable to the liquid fuels industry, which includes the pipeline of Petronet as well as gas pipelines. Other industries which are being price regulated at the moment include water, medicine, telecommunication (fixed lines) and postal rates. Although the economic regulatory methodologies for these industries may differ substantially, fact remains that these industries, such as those mentioned earlier in this paper, will also be faced with the calculation and possible inclusion in tariffs of a component to compensate them for the higher costs to replace assets (depreciation) at the end of their lifetimes. The calculation and the principles of replacement depreciation is, therefore, a common denominator in all industries where price control is relevant and selling prices have to be calculated

The adoption of depreciation systems based on current (revalued) values, will produce lower profit figures in a period of inflation (McGee 1981). These figures may be more realistic, but many quoted companies take the view that that they could not voluntarily adopt such methods, because of the lack of taxation recognition and the adverse effect on published earnings figures. It has often been suggested that financial analysts do not make proper allowance for the different methods of depreciation adopted by enterprises and as a result these companies may not have been properly assessed for stock exchange purposes (Kirkman 1975).

Price regulators can apply various methods for depreciation calculation in respect of regulated enterprises or industries, including:

- an average lifetime, relating to physical lifetimes and obtained from external sources, for all assets in a specific industry;
- an average lifetime, relating to physical lifetimes and obtained from external sources, for specific categories of assets in an industry;

- depreciation rates as approved by the relevant Revenue Service;

- the average lifetime as proposed/accepted by a specific enterprise or industry.

These methods could result in differences in regulated prices and, especially in the case of capital intensive industries or enterprises, these differences could be substantial.

The objective of this paper relates mainly to the last method where industries or enterprises propose lifetimes to be applicable to price regulators, in other words, the specific industries or enterprises are partly (or fully) responsible for the selection of the lifetimes. The recommended lifetimes would be based on studies performed by the relevant industries and enterprises of applicable actual lifetimes. Where depreciation lifetimes are shortened, compared to what they should be, the result would be higher annual depreciation amounts to be recovered in the selling prices. By shortening depreciation lifetimes and applying depreciation based on historical cost prices, an automatic provision is made (partially or fully) for replacement value depreciation. The extent to which provision is made for replacement value depreciation in such cases, will inter alia be a function of the difference between the actual and selected depreciation lifetimes, income tax rates, rates at which funds can be re-invested and the extent of the financial gearing ratio in the specific industry or enterprise.

In providing for replacement depreciation, a differentiation should firstly be made between an enterprise with a differentiated "pool" of assets and secondly one with only a single asset. In the first category the assets differ inter alia in respect of type, age, remaining lifetimes, physical condition and geographical distribution. The practical result of such a situation is that a significant part of assets are replaced on an annual basis, with the result that the annual provision for depreciation is to a large extent used to replace assets on a continuous basis. In the latter category, the assets of an enterprise consist mainly of large single assets and replacement takes place on an irregular basis (deferred replacement) with the result that the annual provision for depreciation is not used to finance the continuous replacement of assets and could theoretically (or actually) be re-invested (if a narrow partial [specific] financing policy is followed). The actual situation is normally a situation varying between a completely diversified pool of assets and a single asset enterprise, because it could be argued that a large single asset consists of smaller assets (components or parts).

The ultimate objective of this paper is to calculate the extent of the provision for replacement 
value depreciation in the single asset situation under various circumstances, e. g. lifetimes, inflation rates, re-investment rates and financial gearing, and ultimately to test the sensitivity of the determining variables. Firstly, a description of important terminology will be given and secondly, the applicable assumptions for the approach followed will be discussed. The next section will relate to the development of the formulae to be used for calculation purposes, the testing of the automatic provision for replacement cost depreciation and includes a worked example of the relevant issue based on realistic figures and situations.

\section{Terminology}

It is necessary to address certain terminology which will be used in developing the relevant formulae (Hamman et al 1986). The terminology will be illustrated by using the following example:

\section{Historical cost of equipment: R10 000 \\ Economic and tax lifetime: 5 years \\ Inflation rate: 10 per cent per annum \\ Depreciation is calculated according to the straight-line method over the lifespan of the equipment}

Historical cost depreciation (HD) is equal to the historical cost $(H)$ of the equipment divided by the lifetime $(L)$ of the equipment, i.e. $H D=H / L$ which amounts to R2 000 in the example.

Replacement value (RV) is the historical cost adjusted with the inflation to date, i.e. where $i$ is the annual inflation rate and $n$ is the specific year. In year two, the RV amounts to R11 000.

Replacement value depreciation (RD), in an all equity environment, is the replacement value divided by the lifetime of the equipment, i.e. $R D=R V / L$, which is R2 200 in year 2 . Replacement value depreciation, in a situation where financing is not only by means of equity capital, is adjusted with a gearing factor. This aspect will be discussed in the next section.

Backlog depreciation (BD), also known as the recovery of under depreciation, is intended to reflect a presumed shortage that results from the ongoing detrimental effect of inflation on accumulated depreciation. In its simpler expression, it is equal to the inflation rate (i) multiplied by the accumulated depreciation ( $A C D$ ) of the previous year (composed of historical cost depreciation, additional depreciation and any prior backlog depreciation), i.e. $B D=i \times\left(A C D_{t-1}\right)$. In year 2 , it amounts to $\mathrm{R} 200$, which is $0.10 \times \mathrm{R} 2000$ and in year 3 it is equal to $(0.10 \times(2000+2200+200))$, i.e.R440. Please note that the re-investment of funds is not taken into account in this calculation. The necessity of backlog depreciation will be discussed under a separate heading.

\section{The need for a financial gearing adjustment}

The term financial gearing refers to either the usage of debt (Tweedie \& Whittington 1984) or net monetary liabilities in relation to equity total capital or (net monetary liabilities plus non-monetary liabilities plus revaluation credits). A situation of net monetary liabilities exists when the liabilities (debt plus redeemable preference share capital) exceed the total monetary assets (cash plus trade payables). In both situations that are part of total property, plant, equipment and inventory financed by debt or net monetary liabilities that are hedged (protected) against the higher replacement obligation, if a guaranteed source of debt in the same ratio than the calculated or assumed one.

This means that the income is charged with replacement value depreciation initially and then credited with the hedged portion, i.e. $G \times(R D$ $H D)$, where $G$ refers to the financial gearing ratio as described in the previous paragraph. The net result is that the income should only be charged with the additional cost of maintaining the property, plant and equipment with that part of total capital financed by shareholders. No differentiation is made in this paper between the two different ways to calculate the gearing adjustment, since the objective is not to develop the correct method to calculate the gearing adjustment, but rather to determine the effect of the shortening of depreciation lifetimes in terms of the provision of higher replacement cost.

The application of the gearing ratio may be illustrated by assuming a gearing ratio of 0.40 , property plant and equipment of R1000 (lifetime is 5 years) and an inflation rate of 10 per cent per annum. The plant and equipment are the only assets and it is assumed that it will continue being the case after five years. This means that the total debt (net monetary liabilities) at the present moment amounts to R400 and after five years it would amount to R644.20, i.e. $0.40(1000 \times 1.10)^{5}$, compared to R600 equity at present and R966 within 5 years. The annual depreciation on a replacement basis could be calculated in two ways:

1. $((1000-600+966)) / 5=\mathrm{R} 273.20$, which means the historical cost of the plant and equipment plus the increase in the equity funds which the enterprise must have after 5 years to enable it to generate sufficient debt funds if the gearing ratio is maintained.

2. $200+0.60((1610.5-1000) / 5)=\mathrm{R} 273.20$, which means the historical cost of the plant and equipment plus the increase in the replacement cost (R610.50) multiplied with that portion the enterprise has to provide itself, i.e. (1 - gearing ratio). 
The first of the above two methods, which emphasises the financing viewpoint substantiates the second, which is the normal one in calculating depreciation based on replacement value.

\section{The need for backlog depreciation}

It is clear that, in terms of cash flow generated, replacement cost depreciation based on current replacement cost values is sufficient to fund asset replacement in the multi-asset (diversified) enterprise during periods of inflation (Doenges 1983; Miller 1980), i.e. without providing for backlog depreciation. Specific reference is made to multiasset enterprises, where assets differ in terms of types, lifetimes, age and physical condition, i.e. properly diversified in terms of the composition of the property, plant and equipment (PPE). The result is that not all assets have to be replaced simultaneously, but this process takes place gradually depending on the specific mix of the pool of assets (Doenges \& Hamman 1982).

The exclusion of backlog depreciation in the calculation of replacement cost depreciation is supported by various authors/guidelines/practices. Miller refers to Philips having modified replacement-value theory to suit the needs of management for decision-making and evaluation. But in doing so it ignored backlog depreciation (under depreciation of prior years) (Miller 1980). The author(s) (unknown source \& Page) of the Hofstra Report in the Netherlands postulated that there was no place for backlog depreciation. In the South African guideline 201 (SAICA) it is mentioned that "in businesses where fixed assets (PPE) are replaced on a regular basis, the amounts set aside for current cost depreciation usually provides sufficient funds in each year to cater for that year's asset replacements". The guideline continues that where PPE are replaced on an irregular basis and significant portions of the assets are replaced in particular years, the amount set aside for current cost depreciation may not be sufficient to cater for these replacements (Vorster 2004).

The exclusion of backlog depreciation is normally illustrated by using an example of extreme diversification, e.g. 5 units of equipment with a lifetime of 5 years each and which are replaced by one piece of equipment per annum indicating assets with varying age. In the original example, the replacement value per unit is $\mathrm{R} 11000$ and the replacement cost depreciation amounts to (11000/5 years) x 5 units of equipment which equals R11 000, the amount needed for replacement purposes. To establish in a specific enterprise to what extent it is perfectly diversified in terms of its assets, a comparison could be made between the replacement depreciation for a specific year and the amounts required for the replacement of assets in that particular year. If the replacement depreciation exceeds the replacement depreciation, the enterprise is sufficiently diversified to ignore backlog depreciation. It should, however, be taken into account that the additional depreciation is not tax deductible, with the result that the emphasis should rather be on the cash flow result of the replacement depreciation.

\section{Development of formulae and (a) model(s) to test the effect of lifetime on the calculation of replacement cost depreciation in the single asset situation}

In developing the required formulae to be used in this paper, it is useful to list the assumptions/ basic aspects, although some of them have already been covered:

- The total historical cost of the assets is tax deductible through depreciation.

- Replacement cost depreciation (consisting of additional and backlog depreciation) is not tax deductible.

- The physical lifetime of assets is equal to the depreciation lifetimes accepted by the Revenue Service.

- Replacement cost depreciation should only be provided to the extent that equity capital/nonmonetary assets are used for financing purposes. This means that there is a guaranteed source of debt/monetary liabilities financing to the extent implied by the initial gearing ratio.

- Only the situation of a single asset, although theoretical to a certain extent, is assumed in this paper, i.e. deferred replacement is assumed at the end of the lifetime of the assets.

- Backlog depreciation is provided, because a single asset is assumed.

- The gearing ratio will be used as (a) given figure(s) without focusing on the details of calculating it/them. The reason for this approach is that the paper focuses mainly on the effect of lifetimes of assets on the calculation of replacement cost depreciation. The gearing ratio and the exact method of calculating are certainly important aspects in the calculations in the whole debate on replacement cost accounting, but not relevant for this paper.

- Scrap values at the end of the lifetimes are ignored.

To illustrate the basic notion/principle underlying this paper, a base case will be developed, starting from a simple/basic situation, using a single asset and providing for backlog depreciation. The model to test the sufficiency of replacement value depreciation for a single asset (and with backlog depreciation) appears in Table 1 . The calculation of the various rows is firstly described.

$R V_{t}=R V_{t-1} \times(1+i)$, where $R V=$ replacement value, $i=$ inflation rate 
$H D=H C / l$, where $H D=$ historical cost depreciation and $l=$ lifetime

$A D_{t}=R V_{t} / l-H D_{t}$, where $A D=$ additional depreciation

$B D_{t}=C D_{t-1} \times i$, where $B D=$ backlog depreciation, $C D=$ accumulated depreciation including additional and backlog depreciation and $i=$ inflation rate

$D G_{t}=H D_{t}+(1-g)\left(A D_{t}+B D_{t}\right)$, where $D G=$ depreciation after gearing and $g=$ gearing ratio $A D G_{t}=A D G_{t-1}+D G_{t}$, where $A D G=$ accumulated depreciation after gearing

$D(1-T)_{t}=H D_{t}+\left(D G_{t}-H D_{t}\right)(1-T)$, where $D(1-T)$ $=$ depreciation after $\operatorname{tax}$ and $T=$ tax rate

$A D G T_{t}=A D G_{t-1}+D(1-T)_{t}$, where $A D G T=a c c u-$ mulated depreciation after gearing and after tax

$E(1-T)_{t}=\left(A D G T E_{t-1}+D(1-T)_{t}+A D G T E_{t-1}\right) / 2$ $x(e / 100)$, where $E(1-T)=$ investment income after tax, $A D G T E=$ accumulated depreciation gearing, tax and investment income and e/100 = investment income ( percentage), and

$A D G T E_{t}=A D G T E_{t-1}+E(1-T)_{t}$

The funds needed for asset replacement at the end of the lifetime, i.e. at the end of year 5, could be calculated according to the following formula: $(H C+G(R V-H C))$ which amounts to $(10000+$ $0.5(12762.8-10000))=11381.4$ (the total for the "Accumulated depreciation after gearing" column). This amount is also equal to the total accumulated depreciation, taking into account backlog depreciation and financial gearing adjustments. If income tax is ignored, there is consequently no surplus or shortfall after five years. If income tax is incorporated, then the additional depreciation is not tax deductible and there is a shortfall of $3.6 \%$ (11381.4 - 10967) of the amount required to provide for sufficient replacement funds. As a result of the deferred replacement the depreciation can be re-invested. If the accumulated depreciation after gearing and tax is re-invested at a rate of $3 \%$ after tax, there will be a surplus of $3.6 \%(11793.6-11381.4)$ at the end of the asset lifetime. A re-investment rate of about $1.5 \%$ after tax will result in a breakeven situation after five years and, therefore, will compensate for the loss as a result of the non-deductibility of the additional depreciation for tax purposes. The sensitivity for changes in the values of the input factors is shown in Table 2.

Table 1: Sufficiency of replacement value depreciation for a single asset with backlog depreciation

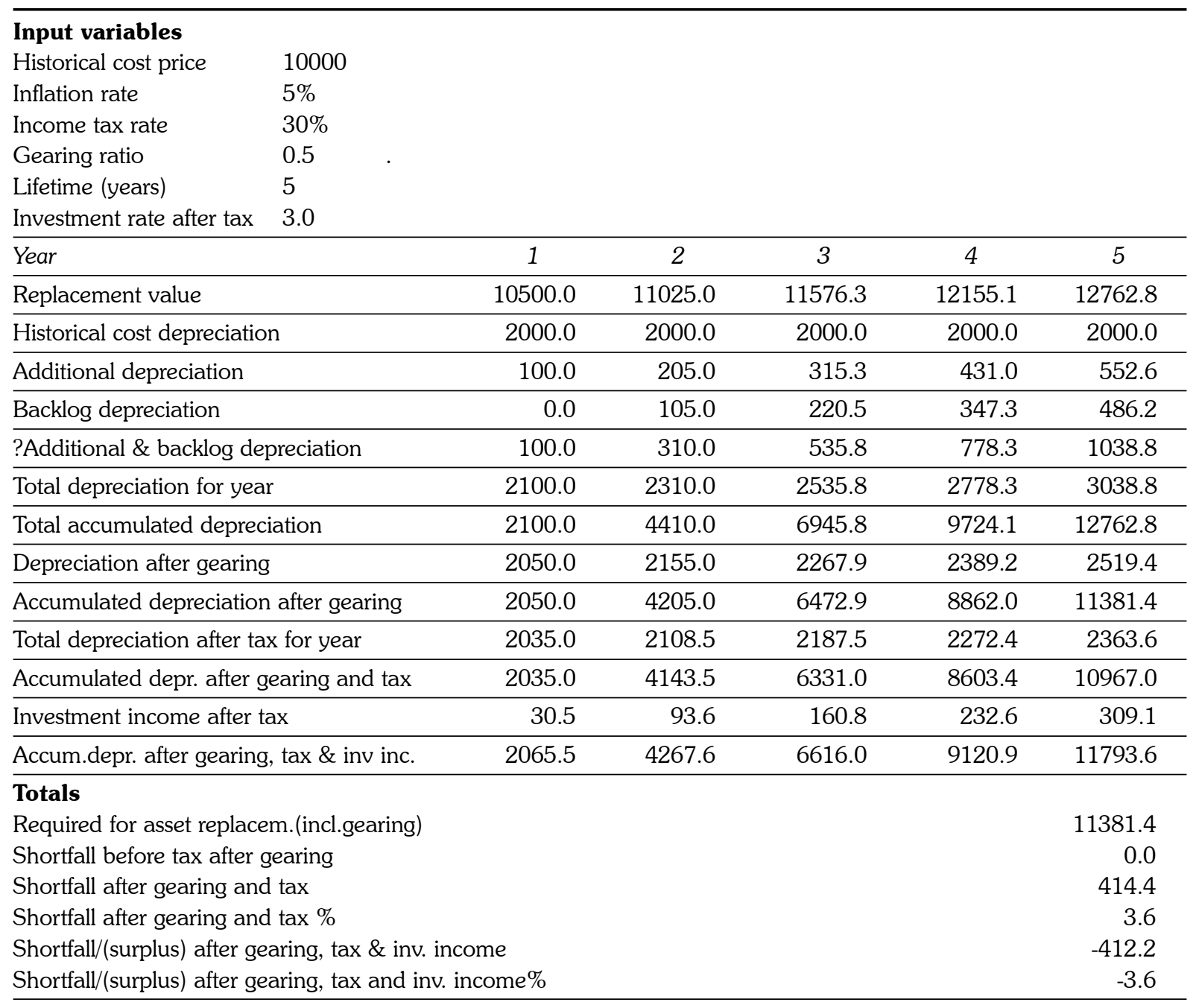


Table 2: Sensitivity analysis of shortfall/ (surplus) \% in the single asset situation

\begin{tabular}{|c|c|c|c|c|c|c|c|c|c|c|c|c|c|}
\hline $\begin{array}{c}\text { Tax } \\
\text { rate (\%) }\end{array}$ & $\begin{array}{l}\text { Inv. } \\
\text { rate (\%) }\end{array}$ & \multicolumn{5}{|c|}{ Inflation rate $=10 \%$} & \multicolumn{7}{|c|}{ Inflation rate $=5 \%$} \\
\hline \multicolumn{14}{|c|}{ Gearing ratio } \\
\hline & & 0.2 & 0.3 & 0.4 & 0.5 & 0.6 & 0.7 & 0.2 & 0.3 & 0.4 & 0.5 & 0.6 & 0.7 \\
\hline \multirow[t]{4}{*}{40} & 10 & -9.2 & -10.9 & -12.7 & $-14,7$ & -16.9 & -19.3 & -17.8 & -18.9 & -20.0 & -21.2 & -22.5 & -23.8 \\
\hline & 7 & -2.0 & -3.5 & -5.1 & -6.9 & -8.8 & -11.0 & -9.7 & -10.7 & -11.7 & -12.8 & -13.9 & -15.1 \\
\hline & 5 & 2.6 & 1.2 & -0.3 & -2.0 & -3.8 & -5.8 & -4.6 & -5.5 & -6.4 & -7.4 & -8.5 & -9.6 \\
\hline & 3 & 6.9 & 5.6 & 4.2 & 2.7 & 1.0 & -0.8 & 0.3 & -0.5 & -1.4 & -2.3 & -3.3 & -4.4 \\
\hline \multirow[t]{4}{*}{30} & 10 & -13.1 & -14.4 & -15.9 & -17.4 & -19.2 & -21.1 & -19.9 & -20.8 & -21.7 & -22.7 & -23.7 & -24.7 \\
\hline & 7 & -5.7 & -6.8 & -8.1 & -9.5 & -11.0 & -12.7 & -11.7 & -12.5 & -13.3 & -14.1 & -15.0 & -15.9 \\
\hline & 5 & -1.0 & -2.1 & -3.2 & -4.5 & -5.9 & -7.5 & -6.5 & -7.2 & -8.0 & -8.8 & -9.6 & -10.4 \\
\hline & 3 & 3.5 & 2.5 & 1.4 & 0.3 & -1.0 & -2.5 & -1.6 & -2.2 & -2.9 & -3.6 & -4.4 & -5.2 \\
\hline
\end{tabular}

Note: Minus figures indicate surplus percentages

The above table covers a wide spectrum of possibilities in respect of the determining factors and from Table 2 it is clear that, as expected, the surplus after tax increases with lower inflation rates, higher gearing ratios, lower income tax rates and higher investment rates. At an inflation rate of $5 \%$ there are virtually no shortfall situations. With an inflation rate of $10 \%$ and the re-investment in the region of $3 \%$ (or lower than $3 \%$ ) the possibility of shortfalls becomes more real.

\section{Analysis of the effect of shorter lifetimes on the provision of replacement depreciation}

In Table 3 the methodology in Table 1 is repeated to measure the sufficiency of historical depreciation amounts for replacement purposes if the depreciation lifetime, which is actually being used, is shortened.

Table 3: Sufficiency of historical cost depreciation if depreciation life is shortened

\begin{tabular}{lrrrrr}
\hline Lifetime (years) & $\mathbf{5}$ & & & \\
\hline Year & 1 & 2 & 3 & 4 & 5 \\
\hline Cost price & 10000.0 & & & & \\
\hline Historical cost depreciation & 2000.0 & 2000.0 & 2000.0 & 2000.0 & 2000.0 \\
\hline Historical cost depreciation after tax & 2000.0 & 2000.0 & 2000.0 & 2000.0 & 2000.0 \\
\hline Investment income after tax & 30.0 & 90.9 & 153.6 & 218.2 & 284.8 \\
\hline Cum. hist. cost depr. incl. inv. income & 2030.0 & 4120.9 & 6274.5 & 8492.8 & 10777.5 \\
\hline
\end{tabular}

\section{Totals}

Required for asset replacement

Lifetime (years)

\begin{tabular}{lrrrrr}
\hline Year & 1 & 2 & 3 & 4 & 5 \\
\hline Cost price & 10000.0 & & & & \\
\hline Historical cost depreciation & 2500.0 & 2500.0 & 2500.0 & 2500.0 & \\
\hline Historical cost depreciation after tax & 2350.0 & 2350.0 & 2350.0 & 2350.0 & 600.0 \\
\hline Investment income after tax & 35.3 & 106.8 & 180.5 & 256.4 & 308.4 \\
\hline Cum. hist. cost depr. incl. inv. income & 2385.3 & 4842.1 & 7372.6 & 9979.0 & 10887.4 \\
\hline
\end{tabular}

\section{Totals}

Required for asset replacement 
Table 3 (continued)

\begin{tabular}{|c|c|c|c|c|c|}
\hline Lifetime (years) & 3 & & & & \\
\hline Year & 1 & 2 & 3 & 4 & 5 \\
\hline Cost price & 10000.0 & & & & \\
\hline Historical cost depreciation & 3333.3 & 3333.3 & 3333.3 & 0.0 & \\
\hline Historical cost depreciation after tax & 2933.3 & 2933.3 & 2933.3 & 600.0 & 600.0 \\
\hline Investment income after tax & 44.0 & 133.3 & 225.3 & 285.1 & 311.6 \\
\hline Cum. hist. cost depr. incl. inv. income & 2977.3 & 6044.0 & 9202.6 & 10087.7 & 10999.4 \\
\hline \multicolumn{6}{|l|}{ Totals } \\
\hline Required for asset replacement & & & & & 11381.4 \\
\hline Shortfall after inv. income and tax & & & & & 382.1 \\
\hline Shortfall after inv. income and tax \% & & & & & 3.4 \\
\hline
\end{tabular}

Lifetime (years)

\section{2}

\begin{tabular}{lrrrrr}
\hline Year & 1 & 2 & 3 & 4 & 5 \\
\hline Cost price & 10000.0 & & & & \\
\hline Historical cost depreciation & 5000.0 & 5000.0 & & & \\
\hline Historical cost depreciation after tax & 4100.0 & 4100.0 & 600.0 & 600.0 & 600.0 \\
\hline Investment income after tax & 61.5 & 186.3 & 262.4 & 288.3 & 315.0 \\
\hline Cum. hist. cost depr. incl. inv. income & 4161.5 & 8447.8 & 9310.3 & 10198.6 & 11113.5 \\
\hline Totals & & & & & 11381.4 \\
Required for asset replacement & & & & 267.9 \\
Shortfall after inv. income and tax & & & & 2.4 \\
Shortfall after inv. income and tax $\%$ & & & & \\
\hline
\end{tabular}

Lifetime (years)

\begin{tabular}{|c|c|c|c|c|c|}
\hline Year & 1 & 2 & 3 & 4 & 5 \\
\hline Cost price & 10000.0 & & & & \\
\hline Historical cost depreciation & 10000.0 & & & & \\
\hline Historical cost depreciation after tax & 7600.0 & 600.0 & 600.0 & 600.0 & 600.0 \\
\hline Investment income after tax & 114.0 & 240.4 & 265.6 & 291.6 & 318.3 \\
\hline Cum. hist. cost depr. incl. inv. income & 7714.0 & 8554.4 & 9420.1 & 10311.7 & 11230.0 \\
\hline \multicolumn{6}{|l|}{ Totals } \\
\hline Required for asset replacement & & & & & 11381.4 \\
\hline Shortfall after inv. income and tax & & & & & 151.4 \\
\hline Shortfall after inv. income and tax \% & & & & & 1.3 \\
\hline
\end{tabular}

Tax allowance is only applicable for the depreciation lifetime approved by the Office of the Revenue Services. For example, in the case of a lifetime of 3 years in the table, the after tax figures for the first years are $(2000+(1333 * 0.7))$. In years 4 and 5 only the depreciation allowances $(2000 * 0.3)$ are taken into account. Based on the figures in the base case it appears as if the shortening in lifetime does have a significant effect on the provision for higher replacement costs. The shortfall decreases from $5.1 \%$ in the case of depreciation over the maximum lifetime of 5 years, to $1.3 \%$ in the case of a complete write-off in year 1 for the example used in Table 1 . The effects of changes in the inputs should, however, be considered before a final conclusion could be made. This is done in Table 4.

The conclusions from Table 4 are the following:

- A lower inflation rate affects the shortfall favourably, because it reduces the amount required for the replacement of the asset at the end of the lifetime of the assets.

- The higher the gearing rate becomes, the lower the shortfall figures or the higher the surpluses become, because of the hedging effect and the favourable impact on the replacement cost. In the case of a gearing ratio of 0.8 , most of the situations show surpluses, while in the case of a gearing ratio of 1 , all the situations reflect surpluses.

- A higher tax rate increases the shortfall 
Table 4: Sensitivity analysis of shortfall/ (surplus) \% when depreciation lifetimes are reduced in the single asset situation

\begin{tabular}{|c|c|c|c|c|c|c|c|c|c|c|c|c|c|}
\hline \multirow{3}{*}{$\begin{array}{l}\text { Tax } \\
\text { rate } \\
\text { (\%) }\end{array}$} & \multirow{3}{*}{$\begin{array}{l}\text { Inv. } \\
\text { rate } \\
(\%)\end{array}$} & \multicolumn{12}{|c|}{ Inflation rate $=10 \%$} \\
\hline & & \multicolumn{12}{|c|}{ Gearing ratio } \\
\hline & & \multicolumn{3}{|c|}{0} & \multicolumn{3}{|c|}{0.4} & \multicolumn{3}{|c|}{0.8} & \multicolumn{3}{|c|}{1} \\
\hline & & \multicolumn{12}{|c|}{ Lifetime used for depreciation } \\
\hline & & 5 & 3 & 1 & 5 & 3 & 1 & 5 & 3 & 1 & 5 & 3 & 1 \\
\hline \multirow[t]{3}{*}{40} & 10 & 20.4 & 15.9 & 10.9 & 6.2 & 0.9 & -5.0 & -14.3 & -20.7 & -27.9 & -28.2 & -35.4 & -43.5 \\
\hline & 6 & 27.9 & 25.4 & 22.7 & 15.0 & 12.1 & 8.9 & -3.5 & -7.1 & -10.9 & -16.1 & -20.1 & -24.5 \\
\hline & 2 & 34.7 & 34.0 & 33.2 & 23.1 & 22.2 & 21.2 & 6.3 & 5.2 & 4.1 & -5.1 & -6.4 & -7.6 \\
\hline \multirow[t]{4}{*}{30} & 10 & 20.4 & 15.2 & 9.3 & 6.2 & 0 & -6.9 & -14.3 & -21.7 & -30.2 & -28.2 & -36.6 & -46.1 \\
\hline & 6 & 27.9 & 25.0 & 21.8 & 15.0 & 11.6 & 7.9 & -3.5 & -7.7 & -12.2 & -16.1 & -20.8 & -23.3 \\
\hline & 2 & 34.7 & 33.8 & 32.9 & 23.1 & 22.0 & 20.9 & 6.3 & 5.0 & 3.7 & -5.1 & -6.6 & -8.1 \\
\hline & \multicolumn{13}{|c|}{ Inflation rate $=5 \%$} \\
\hline \multirow[t]{3}{*}{40} & 10 & -0.5 & -6.1 & -12.5 & -10.0 & -16.1 & -23.1 & -21.5 & -28.3 & -36.0 & -28.2 & -35.4 & -43.5 \\
\hline & 6 & 9.0 & 5.9 & 2.5 & 0.4 & -3.1 & -6.8 & -10.0 & -13.8 & -18.0 & -16.1 & -20.1 & -24.5 \\
\hline & 2 & 17.6 & 16.7 & 15.7 & 9.8 & 8.8 & 7.7 & 0.4 & -0.8 & -2.0 & -5.1 & -6.4 & -7.6 \\
\hline \multirow[t]{3}{*}{30} & 10 & -0.5 & -7.0 & -14.5 & -10.0 & -17.2 & -25.3 & -21.5 & -29.4 & -38.4 & -28.2 & -36.6 & $\overline{-46.1}$ \\
\hline & 6 & 9.0 & 5.3 & 1.4 & 0.4 & -3.6 & -8.0 & -10.0 & -14.5 & -19.3 & -16.1 & -20.8 & -25.9 \\
\hline & 2 & 17.6 & 16.5 & 15.3 & 9.8 & 8.6 & 7.3 & 0.4 & -1.0 & -2.4 & -5.1 & -6.6 & $\overline{-8.1}$ \\
\hline
\end{tabular}

(decreases the surplus), because of higher cash outflow as a result of taxation on the investment income.

- As expected, a higher re-investment rate has also a positive outcome on the final result. When the re-investment rate is high, inflationary adjustments for depreciation may in most cases be ignored. It is only when the gearing ratios are low and the inflation rate high that shortfalls would occur.

- There are a number of situations representing very normal circumstances, i.e. moderate gearing, inflation and re-investment rates, where shortfalls are converted into surpluses when depreciation lifetimes are shortened. Even the shortening of the actual lifetimes may be moderate, e.g. the shortening from 5 to 3 years.

Before the total situation is evaluated, the sensitivity of the determining values should be analysed. This is done in Table 5.

From Table 5 it is clear that upward or downward changes affect the final result similarly except in the case of the lifetime. The reason for this difference would be that the model has to be adjusted manually (3.3 and 2.7 years compared to the base value of the 3 years) to be able to incorporate these changes in lifetime and there will be no "straight-

Table 5: Sensitivity of the determining factors on the surplus/ shortfall in the single asset situation

\begin{tabular}{lccccc}
\hline Input factors & Base case values & \multicolumn{2}{c}{ Incr. $10 \%$} & \multicolumn{2}{c}{ Decr. $10 \%$} \\
\hline Inflation & & Sh / (S) & $\% \Delta$ & Sh / (S) & $\% \Delta$ \\
\hline Gearing & $5 \%$ & 4.642 & 38 & 2.062 & 38 \\
\hline Tax & $50 \%$ & 2.169 & 35 & 4.516 & 35 \\
\hline Investment rate & $30 \%$ & 3.832 & 14 & 2.873 & 14 \\
\hline Shorter lifetime & $3 \%$ & 2.44 & 27 & 4.267 & 27 \\
\hline
\end{tabular}

Notes to Table 5:

1. The base case scenario (Table 1) is identical, except for the shorter lifetime of 3 years used above. The initial shortfall of the variables (base case) is a shortfall of $3.357 \%$.

2. The $\mathrm{Sh} /(\mathrm{S})$ columns indicate the shortfall or surplus percentages.

3. The $\% \Delta$ columns indicate the percentage change from the base case value of $3.357 \%$.

4. The value of only one input factor is changed per time except in the case of the taxation, which has as a result that the re-investment rate after tax has also to be adjusted simultaneously with the tax rate. 
line" relationship. It appears that the most sensitive factors are the inflation rate, the gearing ratio and the re-investment rate. Tax has two consequences; the one increasing the shortfall (decreasing the surplus) and the other decreasing it (increasing the surplus). If the tax rate increases, the tax benefit of annual depreciation amounts increases (and affecting the end result positively) while the investment returns decrease (affecting the end result negatively). The sensitivity of the lifetime and taxation rates used in the calculations is lower than those of the other factors.

\section{Conclusions and recommendations}

In the single asset situation a provision is often made for backlog depreciation and it is also quoted as such in literature studies. From Tables 1 and 2, it is clear that there are mostly surplus situations when accumulated amounts are re-invested. It is predominantly in the case of low investment returns that shortfall situations arise and the same would apply in the case of high inflation rates. Under conditions of high inflation rates, one would expect that the shortfall rates would also increase. When Tables 3 and 4 are analysed it is firstly clear that the shortening of the depreciation lifetime has definitely a significant effect on the sufficiency of the accumulated historical cost depreciation, after provision made for investment returns, to provide for the higher replacement cost as a result of inflation.

The sufficiency of shortening the lifetime of assets would mainly depend on the applicability of inflation, gearing and the investment rates. The lower the inflation rate, the higher the gearing and the investment rate; the better the chances are that no replacement depreciation would be necessary to provide for higher replacement costs if depreciation lifetimes are shortened in the single asset case. One may go so far as to say that if provision for additional depreciation cannot be eliminated fully, it could be reduced significantly if depreciation lifetimes are shortened. By following this guideline the possible negative market evaluation as a result of the introduction of replacement depreciation, referred to previously in this paper, could be avoided or completely eliminated.

Finally, the question should be addressed as to what extent the single asset situation represents a realistic and practical situation. The factual situation remains that no single asset is "completely" single in the sense that full replacement takes only place at the end of the lifetime. In most cases, the "single" assets consist of a smaller part which has different lifetimes and are replaced at different times. On the other hand, most enterprises have a variety of different types of assets requiring different replacement moments. The practical situation would, therefore, tend to vary between the single and multi-asset cases, because a specific situation could tend towards a single asset situation or towards a multiasset situation. If - contrary to expectation - the single asset situation does not require any replacement depreciation to a large extent, the combined diversified and single asset situation could result in a significantly reduced need for replacement depreciation. It would, therefore, also be necessary to analyse the multi (diversified) asset situation in more detail before a more meaningful and final conclusion could be reached on whether the shortening of depreciation lifetimes would decrease or possibly even eliminate the need to provide for a higher replacement cost (Hamman \& Lambrechts 1985).

\section{References}

Archer, A A. Aspects of financial policy under inflationary conditions. Stellenbosch: University of Stellenbosch, Occasional Paper No. 1, 1981, pp. 5-7.

Bakker, P. Inflation and profit control. Toronto and London: Methuen Publications, 1974, pp. 1-2.

Baumol, W J (Ed.). Public and private enterprise in a mixed economy. New York: St. Martin's Press, 1980, p.93.

Doenges, C. The impact of depreciation method and project life on NPV under inflation. Texas, USA: Publication of the University of Texas at Austin, 1983, pp. 1-2.

Doenges, C. The impact of depreciation method and project life on NPV under inflation. Texas, USA: Publication of the University of Texas at Austin, 1983, p 4.

Doenges, R C., and Hamman, W D. Adequacy of machinery investment allowance. Stellenbosch: University of Stellenbosch, Occasional Paper No. 4, 1982, pp.1-19.

Doppegieter, J J and Lambrechts, I J. A capital investment approach to price formulae/determination. South African Journal of Business Management, 16(1), 1985, pp.35-39.

Doppegieter, J J and Lambrechts, I J. A financial evaluation of price formulae. South African Journal of Business Management, 16(2), 1985, pp.98-102.

Doppegieter, J J, Hamman, W D and Lambrechts, I J. Tariff policies for public utilities: The accounting cost approach. Studies in Economics and Econometrics, 13(2), 1989, pp. 49-57.

Doppegieter, J J, Hamman, W D and Lambrechts, I J. The importance of public utilities in South Africa. Studies in Economics and Econometrics, 13(2), 1989, pp. 37-47.

Ernst \& Whinney Report. Depreciation, salvage and cost removal: Critical analysis. Washington: 1982, pp. I-1 to I-6.

Hamman, W D and Lambrechts, I J. Depreciation based replacement value: Ratio to historical depreciation (title translated). Accountancy SA, December 1985, pp. $455-457$. 
Hamman, W D, Lambrechts, I J and Doenges, R C. A conceptual model to test the sufficiency of replacement cost depreciation. Texas, USA: Working Paper of the Department of Finance, Graduate School of Business, University of Texas at Austin (Paper delivered at the Financial Management Association (FMA) meeting in New York),1986, pp. 1-2.

Howe, K M and Rasmussen, E F. Public utility economics and finance. New Jersey: Prentice-Hall, Inc., Englewood Cliffs, 1982, pp. 29-36.

Kirkman, P R A. Inflation accounting - A guide for nonaccountants. London: Associated Business Programmes, 1975, pp. 14-15.

Kirkman, P R A. Inflation accounting - A guide for nonaccountants. London: Associated Business Programmes, 1975, p 30.

McGee, R. Accounting for inflation. New Jersey: Prentice Hall, Inc Englewood Cliffs, 1981, p 159.

Miller, E. Inflation accounting. New York and London: Van Nostrand Reinhold Company, 1980, p 82.

MILLER, E. Inflation accounting. New York and London: Van Nostrand Reinhold Company, 1980, p 82.

Nelson, R A and Primeaux, W J. Rate base valuations procedures and the behaviour of regulated firms. Quarterly Review of Economics and Business, 24(4), 1984, pp.72-81.

South African Institute of Chartered Accountants (SAICA). Disclosure of effects of changing prices on financial results. AC 201.Johannesburg: SAICA, Par. 48.2 .

Turvey, R and Anderson, D. Electricity economics: Essays and case studies. Baltimore and London: The John Hopkins University Press., 1977, pp.6-19.

Tweedie, D and Whittington, G. The debate on inflation accounting. Cambridge: Cambridge University Press, 1984, p 138.

Tysseland, M S and GANDHI, D K. Depreciation, inflation and capital formation in public utilities; one possible approach towards a solution. Quarterly Review of Economics, 19, Spring, pp. 99-113.

UNKNOWN SOURCE and PAGE. Attitude of the Dutch fiscal authorities with regard to inflation. Netherlands.

Unknown source. Hofstra tax report. Netherlands, par.5.2.1.7 and 5.2.1.8 of the Hofstra report.

Vorster, Q, Koornhof, C, Oberholtser, J G I And Koppeschaar, Z R. Descriptive accounting. Durban: Lexisnexis Butterworths, 2004, pp.429-431.

Webb, M G. Pricing policies for public enterprises. New York: The Macmillan Press Ltd., 1976, pp. 11-13. 